\title{
1925年パリ現代装飾美術・工芸美術国際博覧会の敷地選定に関する考察 \\ A STUDY ON THE SELECTIONS AND THE SETTLEMENT OF THE SITE FOR THE INTERNATIONAL EXPOSITION OF MODERN DECORATIVE AND INDUSTRIAL ARTS IN PARIS 1925
}

\author{
三田村 哲哉*，小林 克 弘** \\ Tetsuya MITAMURA and Katsuhiro KOBA YASHI
}

\begin{abstract}
Through the consideration of the transition from the selections and the settlement of the site for the International Exposition of Modern Decorative and Industrial Arts in Paris 1925, the followings are made clear:

1)The site settled at the Esplanade des Invalides, Grand Palais, and etc was admired as ideal, through the considerations of the 12 sites nominated by Louis Bonnier.

2)The total site was composed by some parts of the sites which were possessed by some cadres, the committee of the Colonial Exposition in Paris, Ministry of Public Instruction and Beaux-Arts, the municipal authorities of Paris, and etc, because the parts of the site was conceded by them.
\end{abstract}

keywoods:" International Exposition of Modern Decorative and Industrial Arts in Paris, 1925", Esplanade des Invalides, Grand Palais, Site, Fortifications, Palace of Exposition

1925 年パリ現代装飾美術・工芸美術国際博覧会、エスプラナード・デ・ザンヴァリッド、 グラン・パレ、敷地、パリ城壁跡地、博覧会宮

序

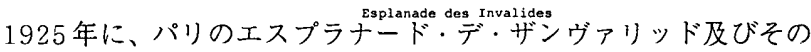

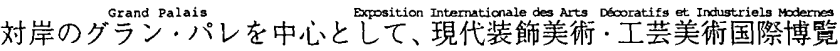
会が開催された。前稿では、その会場の概略に関して、パリで開催さ れた他の博覧会と比較分析を行い、その特徴を明らかにした ${ }^{1) 。 こ れ ~}$ に続き、本稿は、本博覧会の敷地選考から決定に至る一連の検討過程 を明らかにするものである。

本博覧会に関する既往研究は、さまざまな視点から行われているが、 大別すると次の 3 点にまとめることができる。第 1 点目は、本博覧会で 建設された展示館に関する分析である。第2 点目は芸術史の視点から行 われた本博覧会の開催理念に関する考察である。第 3 点目は、1931. 年

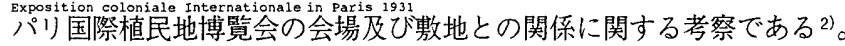
しかし、本稿で行った敷地選定に関する史的考察は、非常にそしい。ま た、本稿は、博覧会計画の企画立案に考察の視点が向けられているとい う点においても、他と大きく異なるものである。さらにこうした考察 は、次稿の研究対象である本博覧会の会場計画並びに、各展示館の建築 造形に関する考察に対しても、意味あるものとなろう。そこで、会場計 画や各展示館の建築造形に関する分析のために、本博覧会の敷地が抱え る条件及び問題点に関する考察も加えて行っている。 また、本博覧会の敷地は、その外形が決定し会場計画の段階に入っ
てからも、それに伴って敷地の部分的な変更が行われている。しか し、本稿の考察対象は、敷地選考が始まる1911年から、その外形が 決定する1921年までとした。尚、本稿は、本博覧会に関する建築資 料だけではなく、注に示す通り、フランス上院及び下院議会の官報、 パリ市議会の公報、各博覧会の協定書及び、本博覧会に関する報告書 と書状を調査・収集し、それらに基づいて考察を行ったものである。

\section{1. 敷地選考と 2 つ候補地}

本博覧会の計画は、1900年パリ万国博覧会閉会後の装飾芸術家等 の不満の高まりから始まった ${ }^{3)} 。 1911$ 年 3 月に装飾美術に関わる各 団体の代表者が参加して、本博覧会の開催に関する検討委員会が発足 した ${ }^{4)}$ 。本博覧会の敷地に関する検討は、この私的委員会において自 主的に始められた。その結果、前回までの博覧会において継続的に利 用されてきた地域に属するグラン・パレとその周辺地域及び、エスプ ラナード・デ・ザンヴァリッドは、敷地として利用することが困難で あると結論づけている5)。その理由は、その広大な敷地を開催期間で ある 6 ケ月及び、建設と解体に要する期間を含めた長期にわたる敷地 の占有が、不可能と判断したからであった。その一方で、解体計画の あるパリ城壁跡地が㬋補地として取り上げられ、特に、、イ

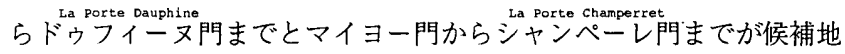

* 東京都立大学大学院厂学研究科建築学徱攻 博士課程・修士 (工学)

** 東京都立大学大学院_工学研究科建築学尃攻 教授·工博
Graduate Student, Dept of Architecture, Faculty of Engineering, Graduate School of Tokyo Metropolitan Univ., M. Eng.

Prof., Dept. of Architecture, Faculty of Engineering, Graduate School of Tokyo Metropolitan Univ., Dr. Eng. 
として報告されている（図-1）。

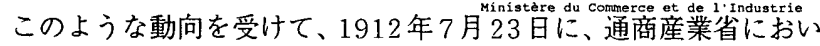
て、博覧会調查委員会が発足し、初めて公的な委員会において博覽会 開催に関する検討が本格的に行われるようになった。一方、建築家

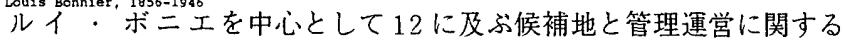
調査・検討も同時に行われていた。そして、1913 年5月23日にその 委員会にお゙いて、博覧会開催に関する報告書が発表される7〕。

それによると、まずこの委員会の定めた 3 つの調査・検討項目が、 本博覧会の「目的と計画」「敷地」、「財政」であったことから、敷地 の重要性を当初から染く認識していたことがわかる8。ささらに、この 報告書では、12の敷地が取り上げられ、その中から具体的な候補地 は、パリ中心部からは西側の郊外に位置するピュトー島とパリ城壁跡 地の 2 地域にまで絞り込まれている（図-1、2）。そして、これらは、 取得に関わる実務的な議論は別として、この博覧会調査委員会として の最終的な結論となり、これに基づいて、これら2つの地域は、本博 覧会の候補地として確保されることとなる。

また、その他の候補地の多くは、パリ城壁跡地の周辺部、またはさら にパリ市の郊外に位置した空閑地である(表-1)。ピュトー島とパり城 壁跡地以外の数地を除外した理由ごとに、大別すると 3 点に分類でき る。第 1 点目は、敷地 $6 、 8 ， 9$ のよに、過去に多くの博覧会が開催さ れたパリ中心部の敷地には、厳しい制約があり、特に開催期間中の交通 問題を理由として除外されている点である(表-1、図-1)。第 2 点目は、 敷地 10、11，12のように、パリ郊外に位置する敷地では、パリ中心部 との隔たりがあることと、特に交通連絡が不便であることを理由に除外 された点である。第 3 点目は、その他の敷地に、敷地の連続性、経済的 問題など、それぞれ個別の除外理由が挙げられている点である9

さらに、候補地に確保されているパリ城壁跡地以外の除外された敷 地にも、パリ城壁跡地周辺部に位置するものがある。一方で、パリの 城壁跡地開発計画が本格化し、ルイ・ボニエも本博覧会計画と並行し て1912 年から.その開発計画に関わっていた10)。また、ルイ・ボニエ が推薦した候補地は、デウデュイユ門からドゥフィーヌ門までの ブローニュの森に沿ったパリ城壁跡地であり、委員会内においても多 くの支持を得ていた（図－2）11)。こうした状況からもわかるように、 ルイ・ボニエは、パリ中心部においての本博覧会開催を望む一方、そ れが困難な場合においては、パリ城壁跡地に関連した敷地において開 催を試みようとしていた意図が表れている。

また、ルイ・ボニエによる敷地の検討は、主に本博覧会の敷地の選 出と、その有効な範囲の面積の計算が主体となっていることがわかる (図-2)。この上うな敷地検討図は、その当時の土地の用途とその範囲 に基つくく分類、その中から本博覧会において敷地として利用可能な範 囲の割り出しとその面積計算を基に描かれている。またここうした面 積の基準となる最小值は、25から 30 ヘクタールであると報告されて
おり、この值は、1900 年パリ万国博覧会において装飾芸術に分類さ れる展示空間の面積を基準としたものであったことがわかる ${ }^{12)}$ 。

一方、この報告書が定める開催年は、1916年とされていたが、当初 の計画から延期を余儀なくされた。そして、1914年の第一次世界大戦 勃発によって、本博覧会の計画はさらなる延期を余儀なくされる。

終戦直後の 1919 年 7 月 2 日に、下院議会において本博覧会開催に 関する審議が再開された。そこで、3 年後の 1922 年に本博覧会を開 表-1 12 の候補地の地域崭囲

\begin{tabular}{|c|c|}
\hline & 候補地 \\
\hline 1 & $\begin{array}{c}\text { L'ile de Puteaux et le champ d'entraiement de Bagatelle } \\
\text { ヒュトー島とバガテルの運動場 }\end{array}$ \\
\hline 2 & $\begin{array}{l}\text { Le Bois de vincennes } \\
\text { ヴrンセーヌの森 }\end{array}$ \\
\hline 3 & $\begin{array}{l}\text { Le champ de Courses d'Auteui1 } \\
\text { ドゥーテュイユの瞕馬場 }\end{array}$ \\
\hline 4 & 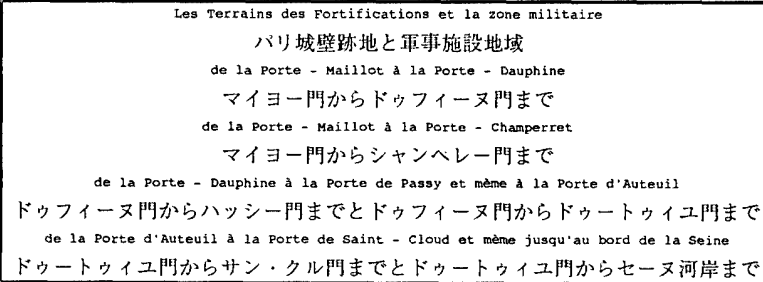 \\
\hline 5 & 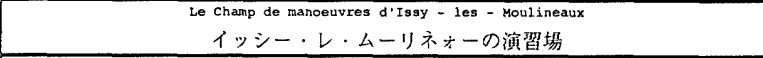 \\
\hline 6 & $\begin{array}{l}\text { Les Jardins du Trocadéro et du Champ-de - Mars } \\
\text { トロカデロとシャン・ドゥ．ママルスの公園 }\end{array}$ \\
\hline 7 & 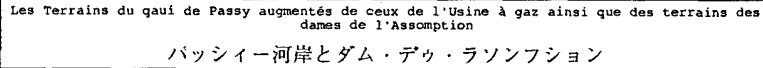 \\
\hline 8 & $\begin{array}{l}\text { Les terrains du Garde-Meuble et du Qaui d'orsay } \\
\text { ガルデゥ・ムッーブルとオルセー河岸 }\end{array}$ \\
\hline 9 & $\begin{array}{l}\text { Le Grand-Palais et Le Petit - Palais avec les jardins du cours - la - Reine et 1·Esplanade } \\
\text { des Invalides }\end{array}$ \\
\hline 10 & $\begin{array}{l}\text { Les terrains du Rond-Point de la Defense et de Nanterre } \\
\text { ラ・デファンスの形㳎場とナンテーレ }\end{array}$ \\
\hline 11 & $\begin{array}{l}\text { Les terrains du Rond-Point situés à viroflay } \\
\text { ヴイロフレイの円形広場 }\end{array}$ \\
\hline 12 & $\begin{array}{l}n s \text { du Rond-point entourant la piece d'eau des suisses } \\
\text { ヴェルサイスのスイス嗔水のある円形広場 }\end{array}$ \\
\hline
\end{tabular}

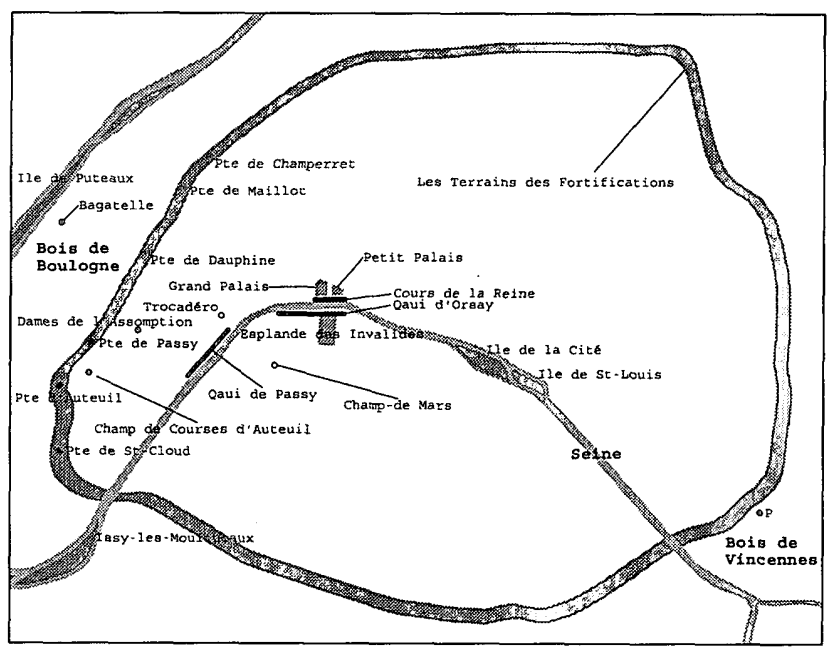

图ー1 ダイヤグラム：バリ城壁跡地を中心とした候補地の位置

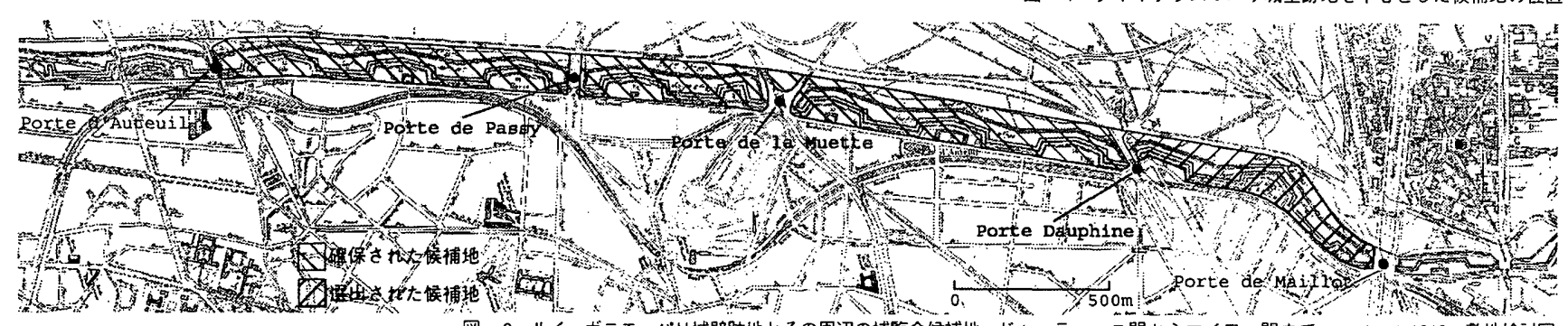
图一2 ルイ・ボニエ、バリ城壁跡地とその周辺の博覧会候補地 - ドゥーテュィユ門からマィヨー門まで、sept-oct. 1919、敷地検討图 
催をすることを確認する。さらに、1919年 12 月から、本博覧会の敷 地選考は、新たに発足した博覧会諮問委顀会だけではなく、パリ市を 中心として審議が展開されるようになる ${ }^{13)}$ 。その中でも、1919年 1.2 月15日に、通商産業大臣の要請に対してセーヌ県知事が推薦した ピュトー島が最有力候補であることは変わらなかった ${ }^{14) 。}$

ここで、当時の敷地に対する評価を整理すると、その長所は、2 点 にまとめられる。第 1 点目は、隣接地であるブローニュの森を博覧会 の敷地として拡張利用できるという柔軟性が認められる点である。第 2 点目は、敷地がブローニュの森に隣接し、豊富な緑地に恵まれてい る点である。その一方で、この敷地の短所は、この候補地の沿岸には、 煙突のある工場が建ち並んでいる点が挙げられている ${ }^{15) 。 ~}$

パリ市議会では、翌年 1920 年 1 月に、この敷地の取得に関する審 議が採択された。しかし、1920年4月23日の審議において、ピュトー 島を本博覧会の敷地に決定することを断念せざるを得なくなる ${ }^{16)}$ 。そ の理由は、地価が第一次世界大戦以前よりも潘かに高騰したこと、さ らに、土地の所有者が極めて高額な要求をしたことが挙げられている 17)。しかし、こうした状況において、ルイ・ボニエは、ほかに7人の 建築家とともに本博覧会の計画に携わるようになる ${ }^{18)}$ 。

\section{2. その他の博覧会等の敷地問題}

一方、本博覧会の敷地決定の遅れが原因で、開催時期が延期される につれて、本博覧会の教地問題に対して、さらに別の新たな問題が生 じた。それは、農業・馬術博覧会宮の建設候補地の問題、1925 年開 催予楚の植民地博覧会の敷地問題、1924 年開催のオリンピックの会 場問題、パリ・フフエアーの会場問題が次々と浮上したことである ${ }^{19)}$ 。 そのため、本博覧会の敷地問題だけをこれらの案件とは個別に取り扱 うことが困難となり、パリ城壁跡地を本博覧会の敷地とする案は、本 博覧会の議論だけの問題ではなくなった。このような理由とともに、 パリ城壁跡地委貝会の意見によって、パり城壁跡地を本博覧会の敷地 とする案は廃案に追い込まれる20)。

実際には、パリ城壁跡地は非常に細長く、また大きな高低差があ り、博覧会会場としての敷地整備は、非常に困難であることも指摘さ れている21)(図-2)。こうした背景には、1919年4月19日のパリ城 壁撤去に関する法案によって、パリ城壁跡地に関する議論が高まり、 これが単に博覧会の敷地だけの問題ではなくパリ市拡張・再開発とい

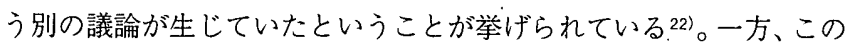
5つの案件がどれも広大な敷地を要すること、大規模な建築が伴うこ となどの共通した問題点を抱えていた。しかし、これらの案件それぞ れが、企画実現に向けて衝突のない調和的解決を望んでいたことと、 このような短期間に、国家的な大規模企画が多額の資金を必要とする

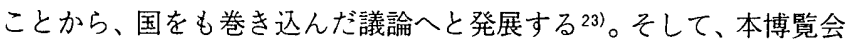
の敷地問題は、他の 4 つの案件とともに議論されるようになる。

そこで、博覧会宮の建設に関する検討が、最初に進められた。そし て、この博覧会宮の議論を中心として、他の博覧会等の敷地問題を検 討するという方針で進められる24)。この博覧会宮は、1889年パリ万国 博覧会において建設された機械館が解体され、これに変わる展示館を 要求する農業関倸者が中心となって提案されたものである ${ }^{25)}$ 。の建 築は、敷地面積が15ヘクタール、建築面積が7ヘクタールという協定 に基づいた規模が決められており、まとまった広大な敷地を要するこ とから、1919年のパリ城壁撤去の法案可決が強く後押しした ${ }^{26)}$ 。
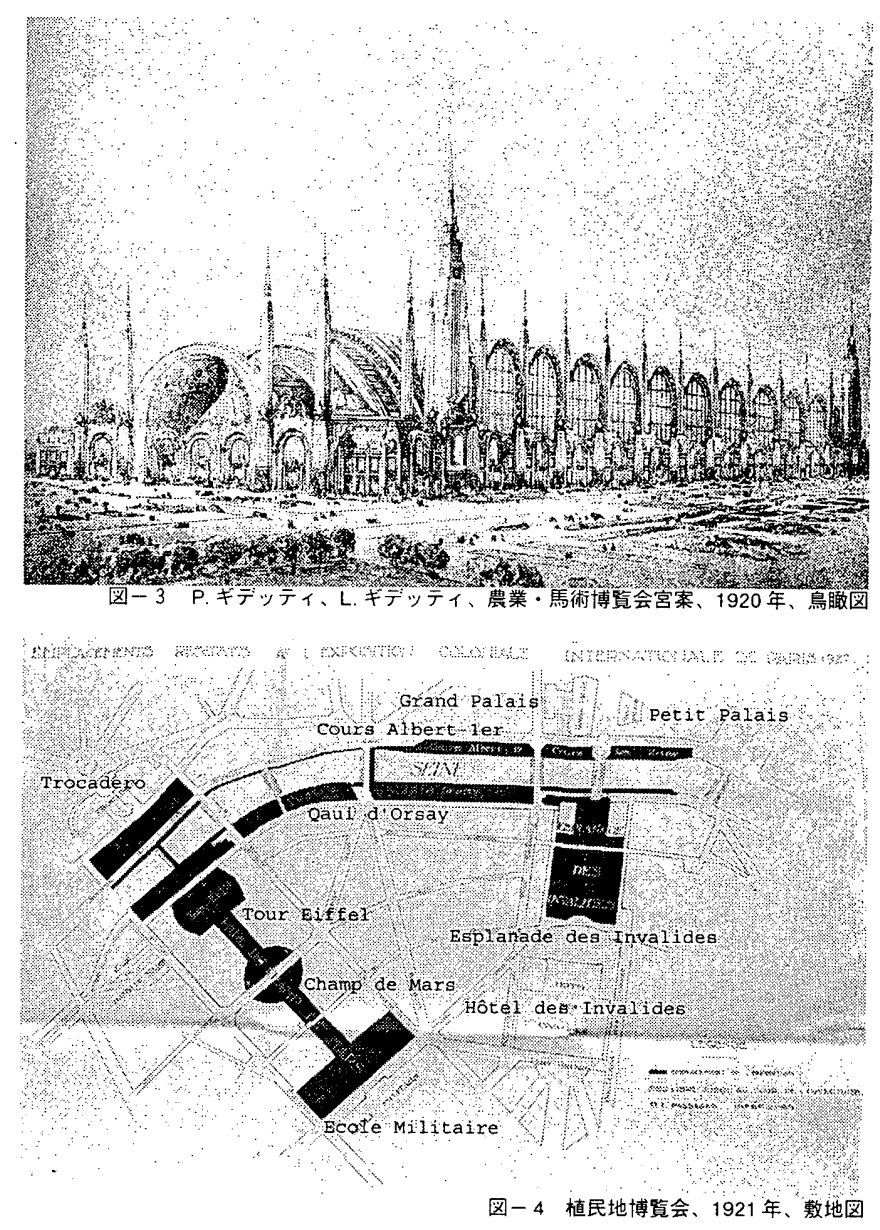

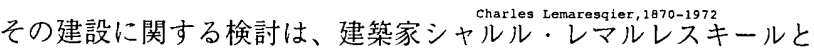
ヴイクトール・ラル・゙ーに委託され、ブローニュ地域についての検討を 行っている。一方、パリ市議会では 1920 年にコンクールを開催した。 そこでは、建築家ルイ・イボリト・ボワローが、鉄骨製の大建築を提 案している27)。さらに、同年に国もコンクールを開催しており、そこ

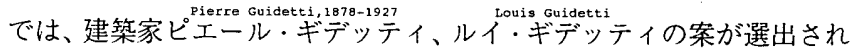
ている ${ }^{28)}$ (図-3)。この案も同様に、大空間を確保する鉄とガラスの大 展示館であった。こうした博覧会宮建設に関する動向は、政治的な動き とともに、パリ城壁跡地及びその周辺に敷地を誘導した。また、会場を 転用するための議論も巻き起こしている。その後、パリ市長の誘致にも

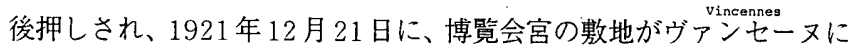
決定した ${ }^{29)}$ (図 -1 , 点P）。さらに、この博覧会宮建設の議論は、最終 的に植民地博覧会の主会場を 1921 年 7 月 11 日決定の敷地とは異なる ヴウンセーヌに誘致する成果も残している(図 -4 )。

\section{3. 敷地の決定}

一方、1920年 10 月に上院議員フェルナン・゙ダヴィが、本博覧会の 博覧会検討委員会委員長に就任し、本博覧会及び植民地博覧会を中心 とした敷地問題の解決に動き出した。このように本博覧会の敷地問題 が全く決定しない状況が続く中で、敷地選考に関する議論が、下院議 会、パリ市議会、博覧会検討委員会それぞれの立場で行われていたの に対して、この委員長交代以後、その議論の場はフェルナン・ダヴィ、 セーヌ県知事、パリ市長及び、植民地博覧会委員長アングルヴァンの

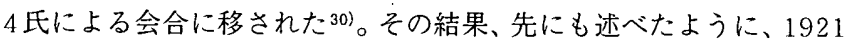
年 7 月 11 日に、植民地博覧会の敷地に関する協定が結ばれ、これに 
よって植民地博覧会の敷地の外形が決定された は、植民地博覧会開催のために、パリ市が国に広大な敷地を利用する 権利を認めるというものである。その敷地の範囲は、1900年パリ万 国博覧会の敷地からトロカデロ宮、グラン・パレ及びプティ・パレを 除いた地域とほぼ同じで、過去に開催された博覧会の中でも相当広範 囲にわたる敷地が用意されている。また、この博覧会の敷地の中に は、博覧会宮建設の議論と関連して、ヴァンセーヌも含まれている 32)。さらにこの協定が結ばれると同時に、フエルナン・ダヴィが、博 覧会宮のような大展示館を提案している。その理由は、植民地博覧会 のみならず本博覧会でも利用可能な建築の検討に入ることによって、 本博覧会の数地問題を再び議論の場に登場させるためである。その一 方で、フェルナン・ダヴィは、敷地問題解決に主眼を置き、決められ た面積の確保と会場の有効利用を優先させた。その結果、博覧会の テーマに関わらず、博覧会宮建設計画の影響を受けて、大展示館によ る敷地問題の解決が、有効である判断していたと考えられる。

しかし、フェルナン・ダヴィは本博覧会をパリの中心部で開催する ことを強く望んでいた。そのため、意欲的なフェルナン・ダヴィの敷 地問題への取り組みに対して、教育・美術省は、本博覧会の会場とし てグラン・パレを利用することに積極的な態度を示した。そこで、教 育・美術省は、本博覧会の会期となる 1924 年 5 月 1 日から 9 月 20 日 までの全面利用を許可する ${ }^{33)}$ 。これに対してさらに、フェルナン・ダ ヴィは、敷地問題解決のために、植民地博覧会委員長アングルヴァン に対して、1921年7月 11 日に協定によって取得した敷地の一部の利 用を要求した。これに対してアングルヴァンは、フェルナン・ダヴィ

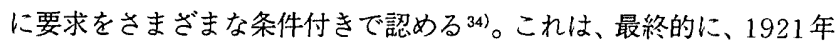
11月 7 日に両博覧会間において協定が正式に結ばれることによって、 本博覧会の敷地の外形がほぼ決定することにつながる（図-5，表-2)。 その敷地は、パリの中心部に位置し、グラン・パレ、エスプラナード. デ・ザンヴァリッドが主要な会場となるように計画されている。しかし、

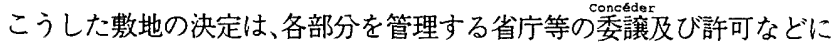
よって成り立っている。ここで記した委譲とは、植民地博覧会が本博覧 会に対して、条件付きでその敷地を払い下げたことを示している。具体 的には、植民地博覧会から委譲された地域は16へクタールあり、クー。 ラ・レンヌ、エスプラナード・デ・ザンヴァリッド、アレクサンドル三

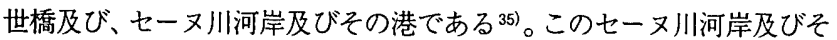
の港は、公共事業省の委議によって利用可能となった敷地であり、これ らはエスプラナード・デ・ザンヴァリッドとグラン・パレが、セーヌ川 によって敷地が分節されているために、この敷地の連続性を高めること を目的として要求したものである。さらに敷地の連続性を高めるために、 パリ市は、クー・ラ・レンヌとグラン・パレの中央車道などの利用を許 可したことによって、本博覧会の敷地の外形が決定した。尚、プティ， パレは清掃を予定しているために、会場から場外されている ${ }^{36) 。}$

一方、この敷地と 1925 年に開催された本博覧会の敷地が、異なる 点は 2 点ある。第 1 点目は、アルベールー世前庭及びその対岸は、 1925 年の開催時には敷地として利用されたが、1921年の時点では 敷地に含まれていない。その理由は、パリ市が1925年7月まで、こ の敷地の貨貸契約を国立園芸協会と交わしていたからである ${ }^{37) 。 ま ~}$ た、クー・ラ・レンヌの路面電車の軌道部分は、1925年開催時には 移設されるために、この部分を敷地として利用しているが、1921年 の敷地決定時においては、移設計画がなかったため敷地外であった。

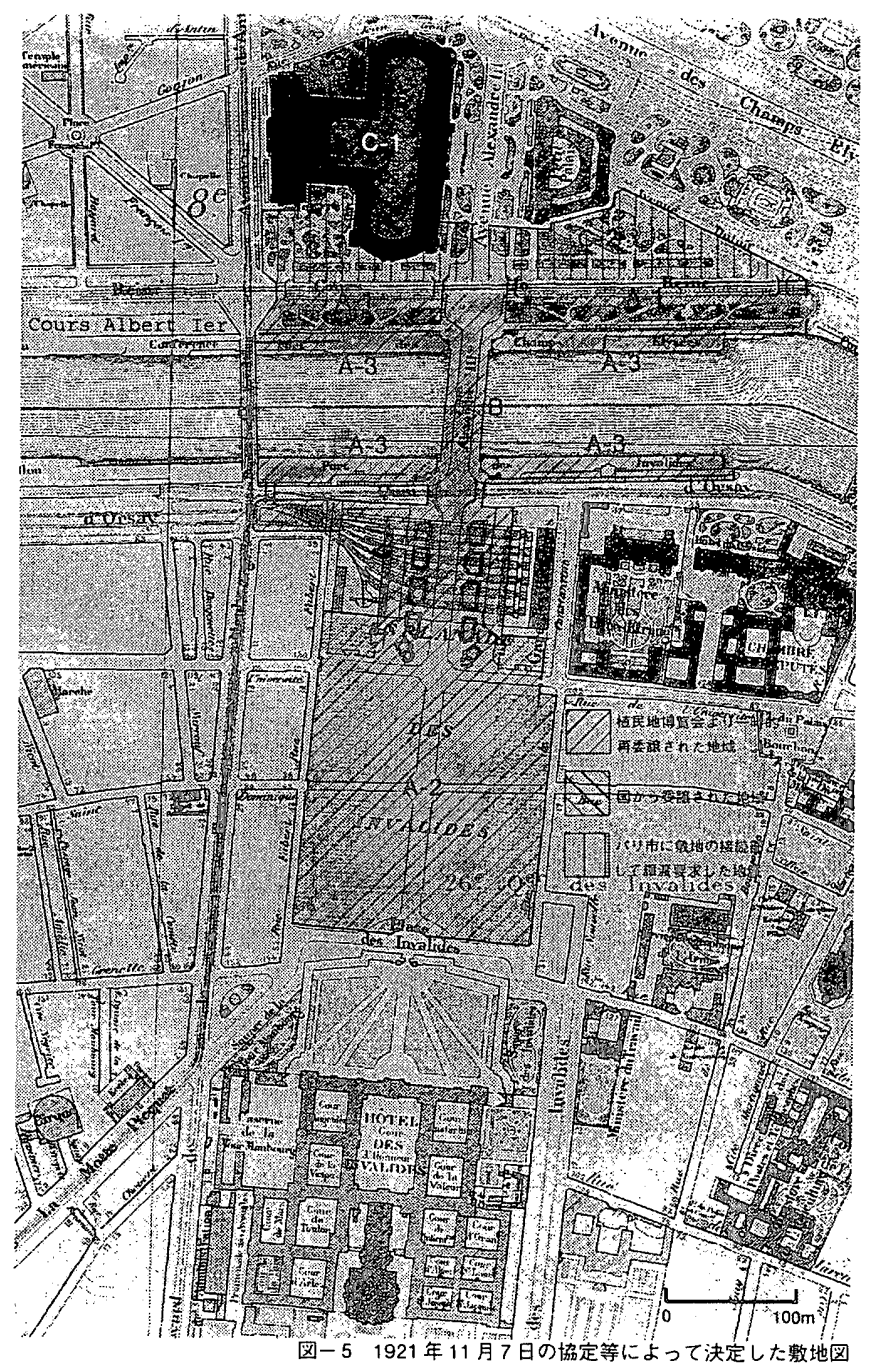

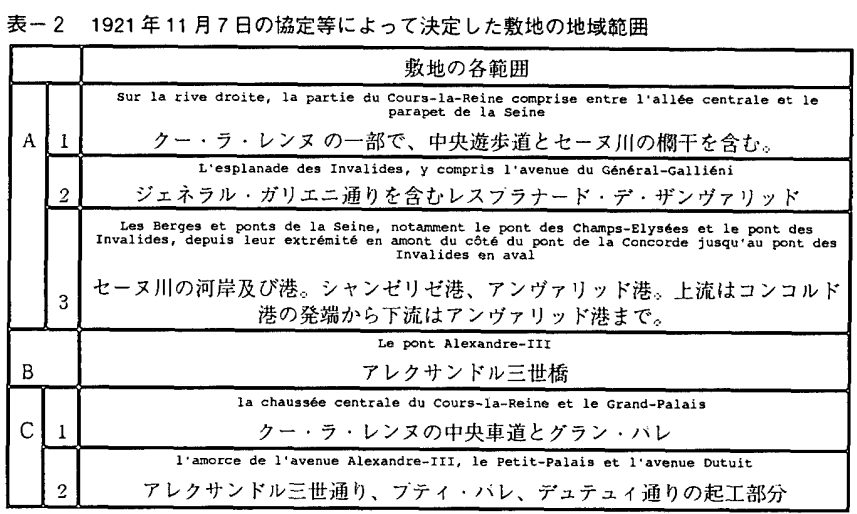

一方、この敷地に対して、一貫して本博覽会の計画に携わってきた ルイ・ボニエの見解は、3点にまとめることができる。第1点目は、こ の敷地がパリ城壁跡地などと比べ、滛かに平坦で広がりがあること、 第 2 点目は、他の有力な候補地に比べ、パリの中心部に近いこと、第 3点目は、他の候補地に比べて、この敷地の周囲が、アンヴァリッド、 グラン・パレ、プティ・パレなどの壮麗な大建築群、セーヌ川及び豊 かな緑によって会場の枠組みが完成していることにまとめられる38)。 また、ルイ・ボニエは、フェルナン・ダヴィの根強い交渉と、パリ市 議会の全会一致した賛成意見によってこの敷地が取得できたことを主 張しており、最終的には、こうした政治的な動向によって敷地問題が 解決したことを意味している。 


\section{4. 敷地の条件と問題点}

このような過程を経て決定した敷地には、本博覧会開催にあたって 多くの条件と問題点を残している。こうした条件及び問題点を大別す ると、以下の 3 点にまとめることができる。第 1 点目は、この敷地を 植民地博覧会より委譲された際に課せられた条件である。第 2 点目は この敷地の地理的及び周辺環境に伴う条件である。第 3 点目は博覧会 開催のために敷地を長期間に渡り占有することによって引き起こされ る交通問題である。

1）植民地博覧会より委锺された際に課せられた条件：この条件は2 点にまとめられ、それらは、本博覧会と植民地博覧会が同一地域を各 博覧会の敷地として利用することによって可能な経費削減を狙ったも のである。そのため、本博覧会の開催は、オリンピック開催と同年の 1924年に延期され、さらに翌年に植民地博覧会を開催することによっ てこうした計画が成り立っている。第 1 点目は、本博覧会の閉会後、利 用できるギャラリー及び展示館等は植民地博覧会においても利用する ために設けられた条件であり、この敷地の各地域ごとに設けられてい る。エスプラナード・デ・ザンヴァリッドに建設されるギャラリーは、 両博覧会で利用すること、またその間に建設される独立館は、植民地 博覽会においても同等の独立館を建設するために、閉会後30日間以内 の解体が義務付けられている ${ }^{39)}$ 。また、クー・ラ・レンヌにおいては、 独立館のみ建設が認められるというものである40)。第 2 点目は、都市 基盤整備に要する負担を両博覧会間で均等に分担しょうとするもので ある。具体的には、本博覧会開催時において、ギャラリー及び展示館 まで、水道、ガス、電気、空気、電話等の配管工事を行うというもの である ${ }^{411}$ 。植民地博覧会は、シャン・ド・マルスにおいても同じ都市 基盤整備を行う必要があったため、大きな負担削減となっている。

2）敷地の地理的及び周辺環境に伴う条件：これは、敷地の連続性に 関する問題である。つまり、それは本博覧会の主要会場であるグラン． パレとエスプラナード・デ・ザンヴァリッドが、セーヌ川によって分断 されている点である。しかし、敷地内にはセーヌ川を渡る橋はアレクサ ンドル三世橋しかなく、博覧会会場内の交通計画に問題を残している。 加えて、その両岸には路面電車の軌道部分があるため、それぞれの両岸 の敖地は、さらに細長く分節されていることも大きな問題点であった。 そのため、開催期間中、博覧会会場内の交通が、路面電車の軌道部分を 通過する交通手段を模索する必要性がまず初めに生じていた。一方、工 スプラナード・デ・ザンヴァリッドのセーヌ川側に、アンヴァリッド 地下鉄駅があることも、敷地の連続性を欠く要素となっている。

3）開催期間中の一般交通に関する問題：これは、1911 年の敷地 検討においても指摘されている。開催期間中の一般交通に関する問題 である。この問題点は、開催期間中の会場内の交通問題とは異なり、 開催に伴って会場周辺の一般交通に生じることが予想される交通問題

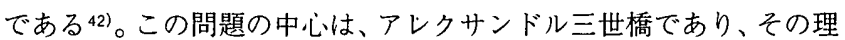
由は、この橋を博覧会会場内専用とすることによって、一般交通が排 除されるからである。パリ市議会では、日常の交通量計算に基づいた 報告などとともに、警察を交えた実務的な議論がなされ、大きな問題 として最後まで議論が継続された ${ }^{43)}$ 。

結

このように、現代装飾美術·工芸美術国際博覧会の敷地選考加決 定に至る検討過程及び、その敷地の抱える条件及び問題点を明らかに
した。こうした一連の考察によって明らかとなった点を整理すると、 以下 5 点にまとめることができる。

第 1 点目は、本博覧会の決定した敷地は、さまざまな条件及び問題 点を抱えているが、多くの敷地検討に基ついいて、最も理想的であると いう高い評価が与えられている点である。第 2 点目は、本博覧会の敷 地が、植民地博覧会等からの委譲によって決定しているため、敷地全 体は各地域を継ぎ合わせたものとなる点である。そして、この敷地が さまざまな条件を抱えた主要な原因は、こうした敷地決定の過程に よって生じたものである。第 3 点目は、この敷地の決定が、最終段階 において、政治的な解決を必要とするが、その決定に至る敷地選考に 関する検討過程においては、ルイ・ボニエによる専門的な敷地に関す る継続的な考察が、重要な役割を果たしている点である ${ }^{44)}$ 。第4 点目 は、本博覧会の度重なる延期の主要原因は、敷地決定の遅れによるも のであった点である。この延期に関する一般的な評価は、本博覧会に 対して否定的なものが多い45)。しかし、本博覧会の敷地という点から 考察すると、この延期が敷地検討に多くの時間を与え、有効なもので あったことが明らかである。第 5 点目は、本博覧会のみならず、他の 博覧会等とともに敷地問題の検討を行ったことによって、パリ城壁跡 地及びその周辺地域の再開発に関する検討を促進している点である。 このように本博覧会の敷地は、糿余曲折した過程を経て決定した。 こうした敷地に対して描かれた会場計画に関する考察は、稿を改めて 述べたい。

註

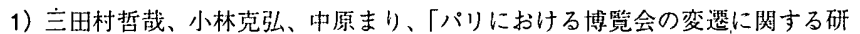
究ー1855-1937 年を対象とした配置計画の分析を中心としてー小、本建築 学会計画系論文集、519号、1999.5、pp.333-339

2）まず吉田鋼市氏の先行研究は、本博覧会の展示館に関する考察が主体であ る。cf.「アール・デコ博とオーギュスト・ペレ小、建筑史学、第 2 号、1984 年 3 月。イヴォンシヌ・ブリュナメエル氏は、開催後 50 周年記念の展覧会など とともに、装飾美術史の視点から総合的な考察を行っている。cf."1925"， Presses de la Connaissance, 1976. また、ナンジーJ.トロ低は、芸 術史の観点から本博臨会の開催理念等に関寸る考察を行っている。cf. Modernism and The Decorative Arts in France - Art Nouveau to Le Corbusier, Yale University Press, 1991.一方、パトリシア A.モルトンシは、1931年に開催きれたバリ植民地博覧会との関倸から政地 に関して部分的な考察がなきれている。cf.Hybird Modernities Architecture and Representation at The 1931 Colonial Exposition,Paris, The MIT Press, 2000.

3）装飾美術に対する不満及び、その普及に関する意見は、本博覧会開催に関 する理念、新しい装飾美術の理念及び、過去の博覧会の調查報告など、本博覽会 開催に问けた社会的な認知を広げるためのものが多かった。例えば、1906

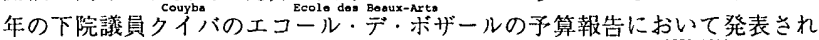
た博覧会開催に関する報告、1909年の美術評論家ロジェール・マンルクスの論 評等が举㓠られる。

4) 装飾美術に関わる各協会とは以下の団体である。芸術産業助成協会 (Société d'Encouragement à l'Art et l'Industrie)、装飾芸術家協会 (Société des Artistes Décorateurs)、装饰芸術地方連合協会 (Société de 1 'Union Provinciale des Arts Décoratifs)、フランス芸術家協会(Société des Artistes français)、ボザール国立協会(Société Nationale des BeauxArts)、サロン・ドートンヌ協会 (Société du Salon d'Autonme)、装飾芸 術中央連合協会 (Société de I'Union Centrale des Arts Décoratifs) 以上7団体である。cf."L'Exposition de 1922,Chronique-Notes et informations", Art et Décoration revie mesuelle d'art moderne, Librairie centrale des Beaux-arts, Paris, sept.-oct.1919, p.17

5) Rapport sur une Exposition Internationale des Arts Décoratifs Modernes Paris 1915, Imprimerie paturel, ler juin 1911，pp.14-15.これは、報告堛には記述がないが、発表年月日及び内谷から、

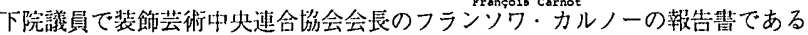


と判断できる。重要な点は、フランソワ・カルノーが、1.912 年2月6日に、 この報告書に基づいて、1915 年に本博覧会を開催するための初めての法案 を提出している点である。Cf.Documents parlementaires-Chambre, ANNEXE №.1641, Imprimerie du Journal officiel, Paris, 6 février 1912,pp.80-81 6）その他の候補地は以下の通りである。バガテルの運動場 (Le Champ d'entraînement de Bagatelle)，デイシー・レ・ムーリネォーの演習場 (Le Champ d'Issy-les-Moulineaux)，ミュエットからポワン・デュ. ジュール門までのパリ城壁跡地 (1'Espace des Fortifications entre la Muette et la Porte du Point du Jour), サン・クル公園 (Le Parc de Saint-Cloud)，ロンシャン競馬場(Les Vaste Hippodromes à longchamp)，オウトゥイユ(Auteil)，ヴアンセンヌ(Vincennes)，サ ン・クル(Saint-Cloud), シャンピヌュ (Champigny), メゾン・ラフィッ テエ (Maisons-Laffitte)，オンニン(Enghien)，サン・オウエン (Saint-Ouen)。また、報告彗、候補地となる地域の数え方などによって、㮢 補地の数え方が異なっている。

7）フェルナン・ジャプサルは、上院議員で芸術産䒚助成協会の会長にあった。 重要な点はこの報告書は、博䜿会開催に関する実質的な調查・検討をまとめ たもので、こうした報告费の最終段階に位置するものに達していると評洒さ れている点である。cf.Fernand Chapsal, "Rapport à M. Le Ministre de Commerce, de L'industrie, des Postes et des Télégraphes", Ministére du Commerce de L'industrie, des postes et des Télégraphes, 23 mai 1913

8) Fernand Chapsal,op.cit.,7),p.2

9) Fernand Chapsal, op.cit.,7),pp.6-8

10）ルイ・ボニエは、パリ市の建筑・公園・庭園部長 (Directeur des Services d'Architecture et des Parcs et Jardins) や建筑.ハ リ美化·搪張部主任娭查官 (Inspecteur Général des Services d'Architecture et d'Esthétique et de l'Extension de Paris) 等の立場にありながら、バリ市の行政側からバリ城壁跡地の開発計画を行っていた。

11) "35-Résolution relative à 1 'aquisition de 1 'île de Puteaux et à l'organisation de l'Exposition internationale des Arts décoratifs modernes" Bulletin municipal officiel de la ville de Paris, Imprimerie municipale, Paris, dimanche 25 avril 1920,p. 2062,2064.

12) Fernand Chapsal,op.cit.,7),p.6

13）博㹂会諮問委員会は、1919年10月29日の政邻によって発足し、70名を 超える委員が巽出きれた。その中に建筑家は、ルイ・ボニエ、コルドニエー

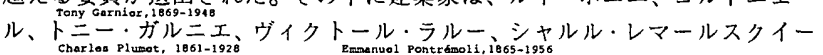

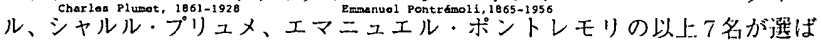
れていた。cf.'Journal officiel de la République Française', 29 oct. 1919, pp.12076-12077

14) Documents parlementaires-Chambre des deputes, ANNEXE No.5825, Imprimerie du Journal officiel,Paris, 19 mars 1923,pp.611-612

15)op.cit.,11),"34-Résolution relative à $I$ 'aquisition de 1 'île de Puteaux et à l'organisation de l'Exposition internationale des Arts décoratifs modernes", samedi 24 avril 1920,p.2043

16) Op.cit.,11),p.2059-2060

17）ビュトー島の所有者は、オーストリアのロスチャイルド家末裔の共同所有 であった。これに加えて、この土地の価格は、第一次世界大戦以前はう00万 フランであったのに対して、この土地の本格的な検討がなきれるようになった 1920年には1800万-2000万フランに価格が急滕した。Op.cit.，11),p.2063

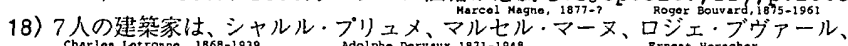

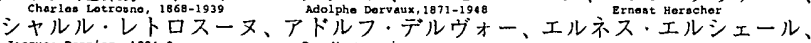

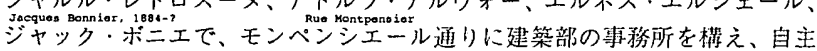
的に設計活動を開始した。cf.Bernard Marrey,Louis Bonnier 1856-1946, Institut français d'architecture, Pierre Mardaga éditeur, 1988, pp.99-100

19) Préfecture du Département de la Seine,Mémoire de M.Le Préfet de la Seine au Conseil Municipal, Imprimerie municipale, Paris, 12 décembre 1921,pp.1-2

20) Préfecture du Département de la Seine,op.cit.,19),p.12

21)Op.cit.,4), “L'Exposition Internationale des Arts Décoratifs Modernes.", nov.1919,p.1

22) Jean-Louis Cohen, Andre Lortie, Des Fortifs au Perif:Paris, les seuils de la ville, Éditions du Pavillon de l'Arsenal, Picard Éditions, Paris, 1991, pp.117-125

23) Préfecture du Département de la Seine,op.cit.,19),p.3
24）本来は、農業・馬術博臨会宮として計画が進められていたが、その建設意 図の変化などから、博覽会宮と記していることもある。同一の計画を示し または、省略した記述であると侾えられる。Préfecture du Département de la Seine,Op.cit.,19),p.4

25) Préfecture du Département de la Seine,op.cit.,19),p.3

26) Préfecture du Département de la Seine,op.cit.,19),p.4

27) Jean-Louis Cohen, Andre Lortie, Op.cit., 22)p.132

28) "Palais des Exposition agricoles", La Construction Moderne, Paris, no.40, ler juillet 1923,p.470

29)Préfecture du Département de la Seine, Op.cit.,19), p.10 30) Op.cit.14), p.612

31) Signé:A.Autrand, A.Sarraut, "Convention relative à 1 'organisation de l'Exposition coloniale.",Paris, le 26 juillet 1921, (Délibération du Conseil Municipale du 11 juillet 1921)

32）植民地博覽会もパリ市との協議を重ね、1921年に最初にパリ市と合意した 計画は、シャン・ト・マルスが、再開発の負担が大きすぎるため、ブローニュ の森のバガテル運動場とパッシー門からマイヨー門までの城壁跡地、また はヴァンセーヌの森を敷地として提案していた。しかし、バガテルを公囷化 することへの不満から前述の敷地に決定したという経緯がある。

33) Lucien Dior,"Lettre de M.le Ministre du Commerce et de l'Industrie à M.le Préfet de la Seine.",Paris, le 10 novembre 1921

34) Signé:Fernand.David, Angoulvant,"Convention relative aux emplacements à concéder éventuellement par l'Exposition coloniale à l'Exposition des arts décoratifs modernes.", Paris, le 7 novembre 1921

35) Lucien Dior, op.cit.,33)

36) Lucien Dior, op.cit.,33)

37) Op.cit.,11),"17.-Modification des emplacements de 1'Exposition internationale des arts décoratifs et industriels modernes.", mardi 10 juillet 1923, p. 3009

38)Louis Bonnier, " $L$ 'Exposition des Arts Décoratifs et Industriels Modernes", Les Travaux Publics, Paris, No.832, avril 1926, p. 54 39) Signé:Fernand David, Angoulvant, "Convention relative aux emplacements à concéder éventuellement par 1'Exposition coloniale à l'Exposition des arts décoratifs modernes.-Convention additionnelle no.1", Paris, le 7 novembre 1921, Article Premier 40) Op.cit., 39), Article.2

41) Op.cit., 39), Article.3

42)Op.cit.,11),"17-Modification des emplacements de l'Exposition internationale des Arts décoratifs et Industriels modernes", mardi 10 juillet 1923,pp.3009-3010

43)Op.cit.,11),"188-Question de M.Emile Massard à M.le Préfet de Police sur les difficultés de la circuration pendant 1'Exposition des arts décoratifs.", mardi 17 juillet 1923, pp. 3170-3171

44)ルイ・ボ二エは、本博覧会以外の他の博覧会計画にも数多く参加しており、 例之ば、1900年パり万国博覧会の会場計画に関するコンクールで入営するな どの実綪も持つ。cf.Institut Français d'Architecture-Centre d'archives d'architecture du xxe siècle, Fonds Louis Bonnier,"Exposition Universelle de Paris 1900,1894, d'Implantation", 35/32

45）吉田鋼市、Op.cit.，2)

\section{図版出典}

図-1 管者作成

目-2 Institut Français d'Architecture-Centre d'archives d'architecture du xxe siècle, Fonds Louis Bonnier, "Exposition des Art Décoratifs de Paris 1925 Dossier de Préparation et Suivi", 35/70，(筆者加筆)

国-3 Op.cit.,28), pl.157

图-4 Archive de Paris,VR/255，(箨者加等)

图-5 Cf. 図-2、筆者加筆)

表-1 簕者作成

表 -2 簕者作成

（2002年7月10日原稿受理，2002年10月30日採用決定 